\section{Post-photography: Lens-based methodology and practice-led ways of critical thinking}

\section{Rodrigo Hill}

\section{The University of Waikato}

Contemporary photographic practice has evolved into a broad field of possibilities, a 'post- photography' moment that comprises fluxes of representational modes to represent experiences, feelings and emotions. In parallel the depth and layering of places offers an exciting challenge to researchers and artists whom are willing to creatively explore the multi- sensorial and spatial 'reality' of places. These thoughts underpin my recently completed practice- led PhD research at Te Awa River Ride, a shared pathway that edges the banks of the Waikato River from Ngāruawāhia to Cambridge, in the central North Island of Aotearoa New Zealand. I explore notions of place and place- making by presenting an installation of photographs titled South of the Rising Sun. I offer this photography installation as a creative milestone which resulted from a methodology of iteration and artistic expression.

The lens- based component of my PhD research covered the construction of a body of photographic work aiming to represent the ways photographic practices and technologies are embedded within the ways we perceive place and create placemaking. My lens- based practice is primarily informed by post- photography methods underpinned by the idea that photographs do not function as pure depictions of reality or single objective representations. On the contrary, I understand photographic practices and images as sources for the construction of multiple meanings. Within this context, I explore the possibilities of a range of camera apparatuses and modes of photographic representation such as documentary, portraiture, landscape and fine art photography.

Lens- based practice therefore is located at the core of my critical thinking processes; a space, which feeds both theoretical and practice- led research approaches. This is the crucial moment when I try to align theoretical frameworks with photographic image construction processes and subsequent curation, sequencing, compilation, design and presentation of images. Processes such as curation, sequencing, compilation and photo narrative construction are key to my lens-based practice. These processes are integral to an iterative methodology of placemaking inquiry connected to four different creative milestones. The stepping through of the creative milestones is intended to allow an understanding of my theoretica framework and research methods and how these work together as part of a complex practice-led research system.

Creative milestones are curatorial research products. They mark points within the overall research time frame. Each creative milestone involved the construction of a photo narrative. The first creative milestone covered the outputting of a photobook while the second involved explorations of digitally based platforms. The third and fourth creative milestones marked further explorations around sequencing, photo montage and photo narrative within photography installation platforms.

My presentation at the 2020 Link Symposium will unpack my lens-based methodology, arguing the ways post-photography practice informs methodological research approaches en route to critical ways of thinking and outputting of artistically based research products. This research model can also be argued as an artistically informed practice-led methodology of place-making.

KEYWORDS

Post-photography, Methodology, Practice-led research, Lens-based, Place-making 